\title{
The relationship of capital structure decisions with firm performance: A study of the engineering sector of
}

\section{Pakistan}

\author{
Abdul Ghafoor Khan \\ Lecturer: Department of Management Sciences, \\ COMSATS Institute of Information Technology, Vehari \\ Email: agk_777@hotmail.com, abdulghafoor@ciitvehari.edu.pk
}

Received: April 22, 2012 Accepted: May 19, 2012 DOI: 10.5296/ijafr.v2i1.1825

\begin{abstract}
Purpose: The purpose of this study is to find the relationship of capital structure decision with the performance of the firms in the developing market economies like Pakistan.

Methodology: Pooled Ordinary Least Square regression was applied to 36 engineering sector firms in Pakistani market listed on the Karachi Stock Exchange (KSE) during the period 2003-2009.

Findings: The results show that financial leverage measured by short term debt to total assets (STDTA) and total debt to total assets (TDTA) has a significantly negative relationship with the firm performance measured by Return on Assets (ROA), Gross Profit Margin (GM) and Tobin's Q. The relationship between financial leverage and firm performance measured by the return on equity (ROE) is negative but insignificant. Asset size has an insignificant relationship with the firm performance measured by ROA and GM but negative and significant relationship exists with Tobin's Q. Firms in the engineering sector of Pakistan are largely dependent on short term debt but debts are attached with strong covenants which affect the performance of the firm.
\end{abstract}

Originality/Value: This is first paper to study an individual sector like engineering industry in Pakistan on the mentioned topic.

Keywords: Capital structure; firm performance; engineering sector 


\section{Introduction}

Capital structure decisions play a pivotal role in maximizing the performance of firm and its valve. Capital structure involves the decision about the combination of the various source of funds, a firm uses to finance its operations and capital investments. These sources include the use of long term debt finance, short term debt finance called debt financing, preferred stock and common stock also called equity financing.

The relationship of the capital structure decisions with the firm performance was highlighted by a number of theories mainly, the agency theory, information asymmetry theory, signaling theory and the trade off theory. The most important among them is the agency problem that exists because ownership (shareholders) and control (management) of firms lies with different people for most of the firms. And for that reason, managers are not motivated to apply maximum efforts and are more interested in personal gains or policies that suit their own interests and thus results in the loss of value for the firm and harm shareholders interests. Therefore, debt finance act as a controlling tool to restrict the opportunistic behavior for personal gain by managers. It reduces the free cash flows with the firm by paying fixed interest payments and forces managers to avoid negative investments and work in the interest of shareholders.

The asymmetric information theory states that the firm managers (insiders) have more information about their firm compared to the outside investors. The well informed managers try to send positive information to the market or ill informed investors to increase the firm value. Signaling theory states that managers have incentives to use various tools to send signals to the market about the difference that exist between them and weaker firms. One of the key tools to send these signals is the use of debt. Employment of debt in capital structure shows that managers have better expectations about the future performance whereas equity sends a bad news about the firm performance in the future.

Various research studies were conducted to check the influence of capital structure decisions on firm performance. As capital structure is mainly based on two sources of finances that is debt and equity. The use of each source of financing show mixed and contradictory results on the firm performance. Hadlock and James, (2002) in his study on undervalued firms found a positive relationship between the use of debt finance and firm performance, as debt finance mainly from banks reduces information asymmetry problems and increases investors confidence in the firm. Simerly and Li (2000) found in their study that environmental dynamism and competitive environment play a key role in making decisions about the optimal capital structure. Firms in the underdeveloped market are faced with financial distress and volatility in interest rates, inflation and tax rates play a significant role in taking decisions about the optimal capital structure decisions (Karadeniz et al. 2009). Pakistan is a developing country and has a very small and undeveloped debt market so firms rely largely on the bank debt to finance its operations and capital investment needs. Since a major proportion of the banks in the country are privatized and they do not issue debt finance on attractive terms. The firms with more uncertain earnings (volatile) earnings find it much more difficult to get to these sources of finances. So the firms with more uncertain earnings are restricted to borrow less in these markets. Similarly, consistently increasing cost of raising finances to run their business smoothly have restricted the firms in Pakistan to largely rely on 


\section{MIN Macrothink}

International Journal of Accounting and Financial Reporting

ISSN 2162-3082

2012, Vol. 2, No. 1

the internal sources of funds because the equity markets are limited and always on lower levels of trading. The existence of information asymmetry problems in the Pakistani market is also a relevant concern in the decisions of capital structure (Sheikh and Wang, 2011).

\subsection{Importance of the Research}

Although substantive research has been done on this subject in the past but most of them was in the developed economies and limited literature is available from the developing countries, especially Pakistan. So, we cannot generalize the results of the developed economies on the developing economies without any research. Eldomiaty (2007) said that capital market in these emerging market countries is incomplete or not efficient compared to the developed market because of the information asymmetry problems. This creates an environment where financing decision are attached with a significant level of irregularities for the firms. For these reasons, it is very essential to evaluate the validity of financial leverage levels and its relationship with the performance of the firms in Pakistan: a developing market economy.

The main importance of this research is that no prior research work was done in the Pakistani market on the relationship of capital structure decisions with firm performance in the engineering sector which is a capital intensive industry where the decisions about optimal capital structure are fundamental to the performance of the firm and it further magnifies the importance of the study. Then due to the fast changes in the socio-political and economic factors specific to the context of Pakistan and the speed with which business are reshaping leading to both structural changes and policy changes demands new and updated information more quickly compared to the past to make optimal decision making. Therefore, all these factors further strengthen the need for an updated research on to mentioned topic.

Section two is focused on the literature related to the capital structure; it includes all of the important theories of capital structure that is concerned with the optimal combination of debt finance and equity finance. Then, the theoretical and empirical studies were highlighted relevant to the study, some of them support the study and some contradicts it. Section three discusses the methodology used to conduct the research study. How and from where the data was collected, variables used, hypothesis statements, the tools and techniques employed. Section four discusses the results and analysis of the research. It includes the descriptive statistics and all regression results obtained. Section five will be based on conclusion of the research. It includes the précis of the research and recommendations. 


\section{Literature Review}

The significance of capital structure theories to firm performance and its value was highlighted by various researchers in their research work over the decades across the developed world. The importance of capital structure theory to firm performance was first highlighted by Modigliani and Miller (1958) stating that the decision about company's capital structure is immaterial to the value of the firm in the absence of taxes, asymmetric information, bankruptcy costs, transactions cost and in an efficient markets with homogeneous expectations. Under these strict assumptions, the type of financing used does not affect the firm value. As the real world markets do not operate on these assumptions and new research work was conducted to test the relationship between capital structure theories with firm performance. Jensen and Meckling (1976) demonstrates that in the decisions about a firm capital structure, the agency conflicts between shareholders and managers is affected by the level of leverage, as it encourage or constrain managers to take decisions in the interest of shareholders and their operating decisions and behaviors affects the firm performance. In similar way, importance of capital structure decisions in firm performance were explored both empirically and theoretically. Myers and Majluf (1984) in their study on firms capital structure said that firms are faced with information asymmetries and transaction costs, so they rely initially on internally generated finances, then move toward debt financing, a relatively expensive form of financing and then move to equity financing as the last option. Jensen (1986) in his free cash flow theory said that excess cash flows are used on less return projects or organization inefficiencies that create agency conflicts among shareholders and managers of the firm and debt is a useful tool to solve the free cash flow problem.

Similarly, trade off theory holds that the decision of a firm about the use of debt finance or equity finance is based on the costs and benefits associated with each source of funds. Like the use of debt can have tax saving benefits but can also have bankruptcy costs, so the company must balance the costs and benefits with each source in deciding about the optimal capital structure. Then an improved version of this theory was capital signaling theory mentioning that all investors are not rational and neither every investor have all amount of information or equal level of information compared to the owners and managers also called insiders of the company. When expected future performance of the company based on the expected future cash flows and earnings will look good, insiders will opt for debt financing with low level of interest and default risk thus reducing the flow of large gains to more shareholders. Whereas in opposite case when expected future performance outlook seems bad, insiders opt for equity financing thus shifting the flow of losses to shareholders, which in case of debt financing would have lead to bankruptcy. Then the agency theory, it explains the relationship of principal (shareholders of the firm) with agent (managers or management of the firm) in the decision making process about the firm capital structure combination. The complexity of the agency problem between principal and agent play a key role in deciding about the optimal capital structure in a firm (Jensen and Meckling, 1976). Then market timing theory which states that firms issue equity finance to generate funds when the market prices (current) or values of the company stocks are high compared to its book value or past market values and buys back these stocks when market values are down for the company (Baker and Wurgler, 2002). These were the main theories that dominated the literature in 


\section{MInstitute Macrothink $^{m}$}

International Journal of Accounting and Financial Reporting ISSN 2162-3082 2012, Vol. 2, No. 1

relevance to the relationship of capital structure decisions with the firms performance over the several decades. Whereas Graham and Harvey, (2001) finds little support for these theories in the actual corporate structures. They find that these theories and their assumptions do not significantly correlate to the determination of capital structure decisions in the corporations. Similarly, Brav et al., (2005) also find that the significance of these theories and its assumptions to the actual capital structure decisions in corporations have decreased overtime compared to the past.

\subsection{Relationship between leverage and firm performance}

Kinsman and Newman (1999) give the following reasons to study the relation between capital structure decisions and firm performance. These reasons are: first, mean debt level in firms have increased to a greater extent over the period of time that require an explanation of the debt level impact on the performance, so that firms can take OCS (optimal capital structure) decisions in the specific circumstances. Second, as the aims of the managers and investors may differentiate, the comparative strengths of the particular effects of debt level on the performance of the firm should be known. Lastly the most important reason for studying the relation of debt level with performance of the firm is to assess the relation between debt level and shareholders wealth, because wealth maximization for shareholders is prime objective for the firms managers.

Many theories have been emerged on the notion of capital structure by various researchers which highlighted that OCS can be attained on balancing the costs and benefits of debt financing (Harris and Raviv, 1990). Similarly, Harkbarth et al. (2006) finds that the decision about optimal leverage level is dependent on balancing the costs of debt (bankruptcy costs) and tax benefit attached to debt, depends on macroeconomic conditions of the country. The target optimal leverage based on the concept of trade off theory depends on the country's economic expansion or recession period as it has cash flow implications. They also find that the expected costs and benefits attached to the use of debt capital is dependent on default risk which is linked to the present state of economy. The significance of the relation between capital structure and firm performance is influenced by the country of origin of the firm (Krishnan and Moyer 1997).

Gleason et al (2000) also found a negative and significant relation of leverage level with firm performance measured by the ROA (return on assets) and profit margin in the European countries. Upneja and Dalbor (2001) on the capital structure of restaurant industry found that firms employ both short term debt finance and long term debt to finance its operations but much dependent on the short term debt. Although it's difficult to obtain debt because of the risky nature of the business, firms with more chances of bankruptcy use short term financing than long term financing. Short term financing can be obtained from local lenders whereas long term debt is linked with information asymmetry issues. Older firms have more long term financing and total financing employed, as they have more confirmed cash flows. Growing firms with more opportunities are more leveraged compared to firms with less growth opportunities.

Chen (2004) analyzed the Chinese firms and said that China corporate environment passes through the transitional phase and some of its characteristics of the modern finance theory are 


\section{MInstitute Macrothink $_{\text {Int }}$}

International Journal of Accounting and Financial Reporting ISSN 2162-3082 2012, Vol. 2, No. 1

similar to developed world; particularly some of the firm related factors are same. But none of the Pecking order hypothesis or tradeoff theory from the developed markets provides any justification for the selection of OCS done by the Chinese firms. These firms seem to have adopted a new order: first utilize retained earnings, then opt for equity financing and lastly the long term debt financing. Deesomsak (2004) in his study on the Malaysian firms found a negative relation of leverage level with firm performance measure by the gross profit margin. Malaysian firms use internally generated source of funds when profits are high supporting the pecking order theory. Further, the relation between the leverage and firm performance in Singapore, Taiwan and Australian firms was negative but insignificant. The affect of firm size on leverage was positive and significant for all the countries except Singapore with an insignificant relationship because firms in Singapore have government support and are less exposed to financial distress costs.

Huang and Song (2006) said that although Chinese market for equity financing are in development phase and firms should have been dependent on the debt capital from banks. But most of the Chinese companies are state controlled and prefer equity financing over debt financing because they still hold the controlling interest and weak laws exist to protect the rights of shareholders. A negative relation exists between leverage measured by long term debt and total debt and profitability measured by the return on assets. Further, larger companies employ more debt and increase in firm size lead to increase in leverage.

Size of the firm is also an important variable of OCS that maximizes performance. Shergill and Sarkaria (1999) found a positive relation between the firm size and the performance in Indian firms. As larger firms have increased diversification, achieves economies of scale, have access to advanced technology and easy for them to obtain funds at lower costs.

Abor (2005) evaluated the relationship of the profitability with capital structure for firms listed on the Ghana Stock Exchange. He found a positive relation for short term debt to total assets and return on equity because of low interest rates. Short term financing represents 85 percent of total debt in Ghanaian firms and is a major component of financing for them. However, a negative relation exists between long term financing and equity returns, as the long term debt was more expensive in that market. The relation among total debt and profitability is positive because of the larger proportion of short term financing in total debt. He suggested that profitable firms are largely dependent on debt as a major source of financing.

Abor (2007) evaluated the relation of capital structure with performance of the firm in small and medium size firms (SMEs) of South Africa and Ghana. He found a significantly negative relation between financial leverage measured by ratio of short term debt, long term debt (significant but positive), total debt to total assets and firm performance measured by gross profit margin for both South Africa and Ghana. Further a negative relation existed among the measures of capital structure and firms performance measured by return on assets in Ghanaian firms.

Zeitun and Tian (2007) in his study on the Jordanian firms found a highly negative relation between the firm performance by employing both market and accounting based variables. Whereas the relation among capital structure variables and firm performance varies across 


\section{MInstitute Macrothink $_{\text {Int }}$}

International Journal of Accounting and Financial Reporting ISSN 2162-3082 2012, Vol. 2, No. 1

industries. The relation is insignificant between capital structure variables and performance variables in the engineering sector firms. Accounting based variables of capital structure were debt (short term, long term and total debt) to total assets and total debt to total equity whereas accounting based measure for performance was ROA. The accounting based measure ROE (return on equity) has an insignificant relation with capital structure in all forms in Jordanian firms. Further, the market based measures for performance was Tobin's Q and price earnings ratio.

Shah and Khan (2007) on the Pakistani firms listed on three Stock Exchanges found a negative and significant relation among leverage levels and performance. They highlighted the existence of possible bias in their finding because many Pakistani firms are family controlled businesses. They inflate production costs and draw the profits from the firms other than dividend. The income statement shows negative profits. The lead to a decline in equity levels and the ratio of debt increases in the overall ratio of financing.

Seppa (2008) found that the Estonian firms follow Peking Order hypothesis in deciding about the optimal capital structure. Estonian firms first utilize internal funds to finance opportunities then move towards external source of financing. Further, large size firms also employ more external funds when internal funds are insufficient to finance opportunities. Large firms obtain funds easily and with less collateral compared to small firms. The choice of capital structure in Estonian firms is also largely influenced by industry specific and country specific factors.

Ebaid (2009) in his study on the emerging market economy of Egypt find that the selection of capital structure mix has a very weak relationship with the performance. He found that the relation among capital structure variables including short term, long term and total debt to total assets has insignificant relationship with performance measured by ROE (return on equity). Whereas, the relation of short term debt and total debt to total assets is negative and statistically significant with the performance. A negative insignificant relation exists for the long term debt with return on assets. Further, the relation of the capital structure with performance measured by the gross profit margin is also insignificant. Omran and Pointon (2009) said that the capital structure is not same for every industry and vary across some of the industries. Further, Egyptian firms with high business risks are not witnessed with low level of capital structure. The contracting sector has employed higher level of debt compared to services sector because of higher tax rate on the service industry confirming the trade off theory. Heavy industries have a positive relation with long term financing sources because of the large assets base employed by the firms.

Bokpin et al. (2010) in his study on the firms of Ghana, a developing market found that debt levels on the Ghana Stock Exchange vary among industries. Firms use high debt levels in their capital structure and prefer the use of short term debts to equity to finance its operations. They find a negative relation between bankruptcy costs and capital structure. Increase in bankruptcy costs lead to a cut down in debt levels by the firms whereas firms assets size has an insignificant relationship with the financial leverage. Onaolapo and Kajola (2010) in their study on the non-financial listed firms in Nigeria found that leverage have a significantly negative relation with performance in Nigerian firms. Due to agency conflicts between various stakeholders, firms have employed high leverage levels which have negatively 


\section{Macrothink}

affected the performance of the firm.

San and Heng (2011) also studied the relation of capital structure with performance of the firm in the Malaysian construction industry in the aftermath of financial crises of 2007-08 that badly affected most of the economies of the world including Malaysia. They found that the financial crises do not show any major impact on the performance of construction industry because of the large scale development work going on the country. Weak relation exists between leverage and performance measured by assets returns, equity returns and profitability in the Malaysian construction industry including small, medium and large size companies.

The empirical studies support the view that optimal capital structure decisions are very critical to the success of the firm and these decisions vary across industries and countries. The importance of the OCS decisions is much more crucial in the capital intensive industries compared to the other industries as huge amount of capital and resources are required to operate these firms. Therefore, a need in the literature was felt that it lacks the research work on the OCS to the firm performance in markets like Pakistan specifically the capital intensive sector like the engineering sector of Pakistan.

\section{Methodology}

\subsection{Data and Sample}

Pakistan is a developing country and has a very thin capital market. This study includes all firms from the engineering sector listed on the KSE (Karachi Stock Exchange) during the period 2003-2009. The data for the research is taken from secondary sources from "Balance Sheet Analysis of Joint Stock Companies listed on the Karachi Stock Exchange" published each year by the Statistics Department of the SBP (State Bank of Pakistan). SBP which is the central bank of the country publishes the Balance Sheet Analysis of all the firms listed on the KSE each year. These firms are categorized in industry or sectors. A total of 9 sectors were made including the engineering sector.

The reason for selecting the engineering sector for the study is that it is a capital intensive industry which requires large amount of capital investment and the business cycles are much larger and returns are witnessed over a longer time period compared to the other industries. The decisions on optimal capital structure are very critical to the success of this particular industry that is the reason for selection this particular industry for the study.

Data is taken from the firms listed in the engineering sector and includes those firms whose data is available for the test period 2003-2009.

Each firm considered in the study sample is based on the same number of time series observations among the panel members, therefore, this panel data of the firm is a balanced panel. The final sample consisted of a total of 36 firms and the firms for which the data for the period of study is not available was not considered in the study. 


\section{Macrothink \\ International Journal of Accounting and Financial Reporting \\ ISSN 2162-3082 2012, Vol. 2, No. 1}

Table I

Distribution of companies by economic groups

\begin{tabular}{|c|c|c|c|c|c|c|c|}
\hline \multirow[b]{2}{*}{ Economic Groups } & \multicolumn{7}{|c|}{ Years } \\
\hline & 2003 & 2004 & 2005 & 2006 & 2007 & 2008 & 2009 \\
\hline Textiles and Cotton & 199 & 189 & 182 & 181 & 180 & 182 & 167 \\
\hline Chemicals Products & 38 & 36 & 34 & 34 & 34 & 35 & 36 \\
\hline Engineering Products & 44 & 42 & 41 & 41 & 41 & 40 & 38 \\
\hline Allied and Sugar Industries & 37 & 35 & 35 & 35 & 36 & 36 & 36 \\
\hline Board and Paper Products & 13 & 12 & 12 & 10 & 10 & 10 & 9 \\
\hline Cement Industry & 22 & 22 & 22 & 22 & 20 & 21 & 21 \\
\hline Energy and Fuel Sector & 24 & 25 & 28 & 28 & 27 & 27 & 27 \\
\hline Transportation Sector & 7 & 13 & 15 & 12 & 12 & 12 & 13 \\
\hline Miscellaneous Sectors & 79 & 77 & 74 & 73 & 77 & 74 & 67 \\
\hline Total & 463 & 451 & 443 & 436 & 437 & 437 & 414 \\
\hline
\end{tabular}

Source: State Bank of Pakistan

Companies in the engineering industry are mainly involved in the production of:

- Engineering goods, machinery \& machinery components

- Light and heavy tractors, motorcycles, auto-rickshaw, panel back window

- Battery products and chemicals

- Automobiles, assembling, chassis, bodies, parts, wheels, tires.

- Casting of steel and iron, different cc \& uPVC pressure pipes, polydex and polythylene pipes etc.

- Power driven pumps, electric motors

- Television, transformers and switchgears, sewing machines, gas appliances, refrigerators / deep freezers

- Electric and telecom cables

\subsection{Variables of the Research}

\subsubsection{Firm Performance}

The literature related to the measures of firm performance show that a number of measures were used to judge the firm performance. Some researchers have used accounting based measure to judge the performance. Accounting based variables of the performance are profitability ratios. Majumdar and Chhibber (1999) and Abor (2005) also used assets returns, equity returns and profitability margins as variables of firm performance.

Welch, (2004) used market based measures for performance. He measured performance by the stock returns and volatility in returns. Further, Zeitun and Tian, (2007) used Tobin's Q 


\section{Mll Macrothink}

International Journal of Accounting and Financial Reporting

ISSN 2162-3082

variable for performance which uses a combination of accounting and market values. Whereas Abor (2007) used both accounting based variables and Tobin's Q based variables to measure performance.

In this study, three accounting based measures and a Tobin's Q based measure of performance were used. The first measure is the return on assets (ROA) which is calculated by taking the ratio of net profit of the firm to the mean total assets of the firm. The second measure will be return on equity (ROE) which is calculated by taking the ratio of net profit of the firm to mean total equity. The third variable of performance will be the gross profit margin (GPM) which will be measured by taking the ratio of gross profit of the firm to total sales or revenues. These are also called profitability ratios. Tobin's Q will be measured by taking the ratio of market value of equity of the firm and total debt divided by total assets.

\subsubsection{Capital Structure (Financial Leverage)}

Literature shows a number of measures of capital structure. Abor (2005 and 2007) and Ebaid (2009) used the three (short term, long term and total debt) to total assets as measures of financial leverage.

In this study we will use three of the most important measures of capital structure. These are measured by:

1) Short Term Debt divided by the Total Assets of the firm (STDTA),

2) Long Term Debt divided by the Total Assets of the firm (LTDTA) and

3) Total Debt divided by the Total Assets of the firm (TDTA)

4) Tobin's Q (TQ)

\subsubsection{Control Variable}

A number of studies from the literature have shown the importance of firm size in influencing the performance. Larger firm have more capabilities and resources, achieve economies of scale and are more diversified (Frank and Goyal, 2003).

Firm size is used as a control variable in the study to check the differences of firm's operating environment in the model. The size of the firm is measured by taking natural log of the totals assets and will be used to check the effect of firm size on the performance. 


\subsection{Conceptual Framework}
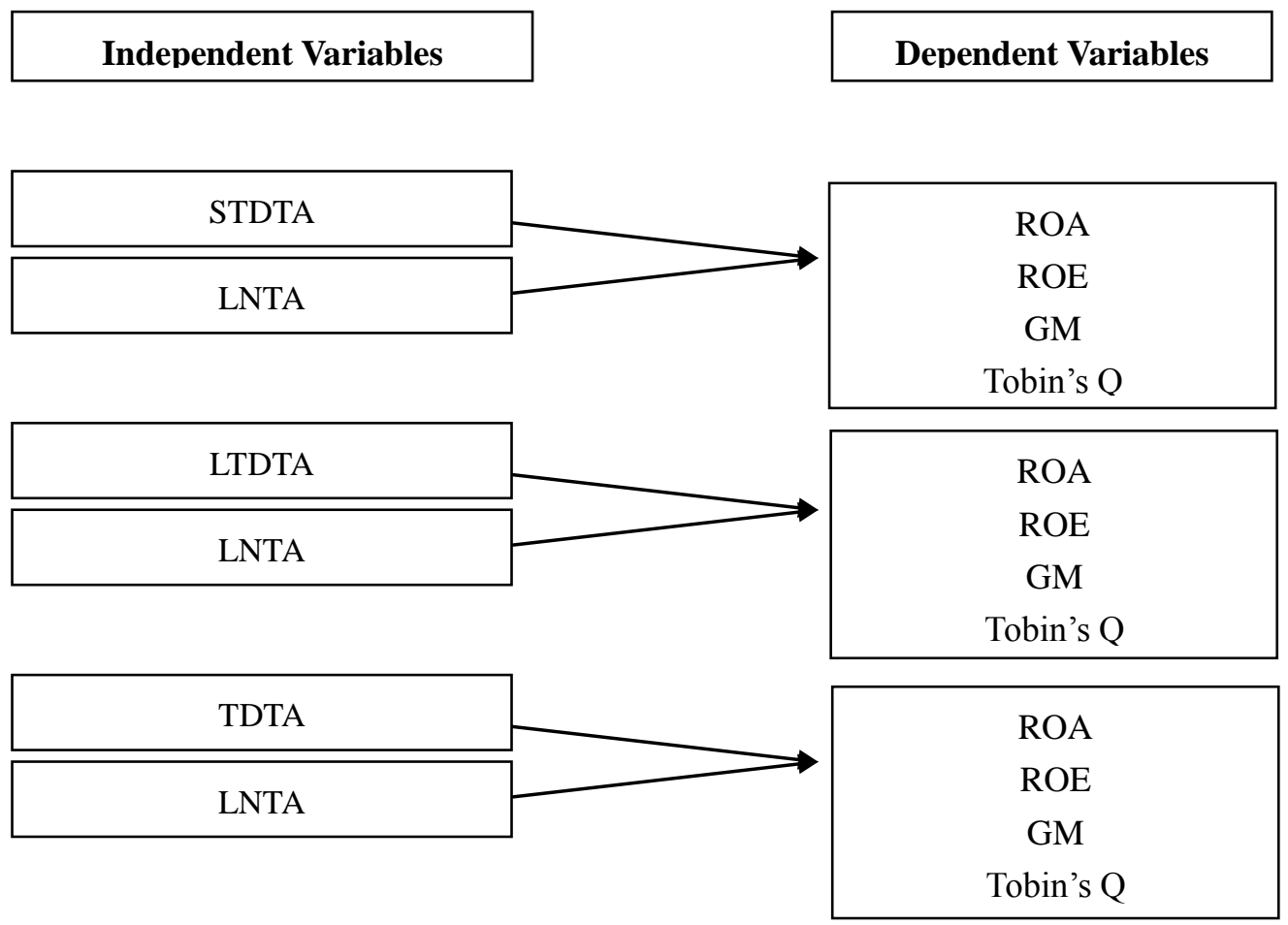

\subsection{Model}

The relationship between the capital structure measured by leverage and a firm's performance will be tested using the regression models explained below (Ebaid, 2009):

Equations

Performance $I, t=\beta 0+\beta 1$ STDTAI $, t+\beta 2 \mathrm{LNTAI}, t+\mathrm{e} I, t$

(1)

Performance $I, t=\beta 0+\beta 1 \mathrm{LTDTA} I, t+\beta 2 \mathrm{LNTA} I, t+\mathrm{e} I, t$

(2)

Performance $i, t=\beta 0+\beta 1 \mathrm{TDTA}, t+\beta 2 \mathrm{LNTA} I, t+\mathrm{e} I, t$

(3)

where

STDTA $I, t=$ short term debt to total assets of the firm $I$ in year $t$

LTDTA $I, t=$ long term debt to total assets of the firm $I$ in year $t$

TDTA $I, t=$ total debt to total assets of the firm $I$ in year $t$

LNTAI, $t=$ logarithm of total assets of the firm $I$ in year $t$

$\mathrm{e} I, t=$ error term 


\section{Macrothink}

\section{Results and Analysis}

\subsection{Descriptive Statistics}

The results in the Table II show a summary of the descriptive statistics for all the variables including the dependent variables and independent variables. Dependent variables are ROA, ROE and GM while independent variables are STDTA, LTDTA and TDTA. To check whether size of the company affect the performance variables, natural log of total assets were taken (LNTA).

Descriptive statistics results show that the mean (median) of the return on assets for the companies in the engineering sector of Pakistan from the period 2003 -2009 is 9.49 (8.4) percent, mean (median) of the return on equity is 19.11 (21.6) percent and mean (median) of the gross profit margin is 9.48 (13.16) percent. These results show a poor performance during the period 2003 - 2009 by the firms in the engineering sector which can be due to a number of reasons faced by Pakistan over the several years. The mean (median) of the short term debts is 52.9 (51.23) percent of the total assets, mean (median) of the long term debts is 9.99 (2.9) percent and mean (median) of the total debt is 62.89 (58.65) percent of the total assets during the period: this result show that about 63 percent of the total assets of the engineering sector companies in Pakistan are financed by debt. This shows that Pakistani companies particularly the companies in this sector operate with significant level of financial leverage. The ratio of short term debt is 53 percent of total assets while the ratio of long term debt is just 10 percent of total assets which shows that the companies in the engineering sector mainly use short term debt to finance it operations and is less dependent on long term debt. This significant dependence of Pakistani companies on the short term debt instead of long term dent could be due the absence of proper or an established public debt market. The only option for Pakistani companies to obtain long term financing is to directly borrow from the banks but they are attached with a lot of restrictive debt covenants that have to be fulfilled by these companies to get continuous supply of funds and make it less favorable for these companies to use this source of financing (Sheikh and Wang, 2011).

\section{Table II Descriptive Statistics}

\begin{tabular}{|l|l|l|l|l|l|l|l|}
\hline & ROA & ROE & GM & STDTA & LTDTA & TDTA & LNTA \\
\hline Mean & 9.49878 & 19.3192 & 9.47943 & 52.9062 & 9.98645 & 62.8931 & 7.46951 \\
\hline Median & 8.4 & 21.6 & 13.16 & 51.23 & 2.9 & 58.65 & 7.48 \\
\hline Maximum & 77.7 & 97.1 & 29.47 & 193.01 & 205.24 & 234.86 & 10.12 \\
\hline Minimum & -50.9 & -608.3 & -403.82 & 6.47 & 0 & 6.52 & 4.6 \\
\hline Std. Dev. & 13.5468 & 47.0317 & 31.8116 & 25.6157 & 21.776 & 29.3594 & 1.29223 \\
\hline
\end{tabular}




\section{Macrothink \\ International Journal of Accounting and Financial Reporting \\ ISSN 2162-3082 2012, Vol. 2, No. 1}

\subsection{Regression Results}

Pooled ordinary least squares regression method is used to find the relationship of capital structure with performance of the firm. The regression equations were run to find the relationship between each of the capital structure measures (independent variables) and the firm's financial performance (dependent variables) called ROA, ROE, GM and Tobin's Q. Further, in the regression equation, the control variable is added by taking log of total assets to check its effect on firms financial performance. R-squared value in the following results is low because the capital structure measured by the three variables, STDTA, LTDTA and TDTA is used as a single independent variable in the relationship. There are a total four regressions for each of the dependent variable (ROA, ROE, GM and Tobin's Q) reflecting the three capital structure measures (STDTA, LTDTA and TDTA).

\section{Table III}

Capital Structure and Firm Performance measured by ROA

\begin{tabular}{llll}
\hline \multirow{2}{*}{ Variable } & \multicolumn{2}{l}{ Performance (ROA) } \\
\cline { 2 - 4 } Constant & 10.984 & 1.728 & Model 3 \\
STDTA & $-0.219(0.000)$ & & 20.255 \\
LTDTA & & $-0.123(0.107)$ & \\
TDTA & & & $-0.259(0.000)$ \\
Log S & $0.921(0.377)$ & $0.595(0.686)$ & $0.315(0.749)$ \\
R & 0.491 & 0.442 & 0.520 \\
F & 68.147 & 56.07797 & 76.514 \\
Sig. & 0.000 & 0.000 & 0.000 \\
\hline
\end{tabular}

Table III shows that short term debt and total debt have a significantly negative effect on the financial performance of the firm measured by return on assets. While the control variable, size of the firm has an insignificant relationship with the performance of the firm measured by ROA. This negative relationship is explained by the higher cost of debt and strong covenants attach to the use of debt. These are consistent with Ebaid (2009; Bokpin et al. 2010; Sheikh and Wang, 2011). Whereas Abor (2007) found a positive relationship between short term debt and return on assets in small and medium enterprises (SMEs) because of the nature of industry in which they are operating and low level of interest rates. 


\section{Macrothink \\ International Journal of Accounting and Financial Reporting

Table IV

Capital Structure and Firm Performance measured by ROE

\begin{tabular}{llll}
\hline \multirow{2}{*}{ Variable } & \multicolumn{2}{l}{ Performance $($ ROE $)$} & Model 1 \\
\cline { 2 - 4 } Constant & -11.968 & -18.562 & -2.916 \\
STDTA & $-0.173(0.133)$ & & \\
LTDTA & & $-0.177(0.191)$ & \\
TDTA & & & $-0.209(0.029)$ \\
Log S & $5.543(0.013)$ & $5.437(0.016)$ & $4.893(0.030)$ \\
R 2 & 0.037 & 0.035 & 0.046 \\
F & 4.758 & 4.477 & 6.071 \\
Sig. & 0.009 & 0.013 & 0.003 \\
\hline
\end{tabular}

Table IV shows that capital structure variables measured by STDTA, LTDTA and TDTA have weak relationship with the financial performance of the firm measured by return on equity. This result is consistent with Zeitun and Tian (2007) and Ebaid (2009). Bokpin (2009) finds a statistically insignificant relationship for STDTA with return on equity in the emerging market economies. Whereas Abor (2005) found a positive and significant relationship between STDTA and ROE. As short term debt was less expensive and employing more short term debt with low level of interest rates have resulted in an increase in profits.

\section{Table V}

\section{Capital Structure and Firm Performance measured by GM}

\begin{tabular}{llll}
\hline \multirow{2}{*}{ Variable } & \multicolumn{2}{l}{ Performance $(\mathbf{G M})$} & Model 3 \\
\cline { 2 - 4 } Constant & 17.667 & -23.379 & 17.195 \\
STDTA & $-0.605(0.000)$ & & \\
LTDTA & & $0.637(0.006)$ & \\
TDTA & & & $-0.484(0.000)$ \\
Log S & $2.918(0.203)$ & $3.540(0.217)$ & $2.724(0.219)$ \\
R 2 & 0.200 & 0.087 & 0.147 \\
F & 14.284 & 5.459 & 9.812 \\
Sig. & 0.000 & 0.001 & 0.000 \\
\hline
\end{tabular}




\section{Al Macrothink}

International Journal of Accounting and Financial Reporting

ISSN 2162-3082

2012, Vol. 2, No. 1

Table V shows that STDTA and TDTA have significantly negative relationship with the performance of the firm measured by GM. Whereas the LTDTA have a positive impact on the performance of the firm due to long term financing obtained by some of the large size companies on reasonable rates. Amidu (2007) has the same findings for relationship between leverage and profitability. This is consistent with pecking order model, as firms generate internal source of finances then move for less favorable finances like debt and equity finances because the costs associated with obtaining these external sources of financing are very high thus make it less favorable for them to largely on them (Abor 2007; Chen et al. 2009)

\section{Table VI}

\section{Capital Structure and Firm Performance measured by Tobin's Q}

\begin{tabular}{llll}
\hline & \multicolumn{2}{l}{ Performance Tobin's Q } \\
\cline { 2 - 4 } Variable & Model 1 & Model 2 & Model 3 \\
\hline Constant & 1.009 & 2.197 & 2.271 \\
STDTA & $-0.009(0.000)$ & & \\
LTDTA & & $0.001(0.050)$ & \\
TDTA & & & $-0.005(0.000)$ \\
Log S & $-0.019(0.017)$ & $-0.163(0.000)$ & $-0.164(0.000)$ \\
R 2 & 0.893 & 0.712 & 0.802 \\
F & 960.4610 & 161.32 & 263.821 \\
Sig. & 0.000 & 0.000 & 0.000 \\
\hline
\end{tabular}

Table VI shows the regression results for the relationship between capital structure measures and performance of the firm measured by Tobin's Q. The results show that a negative and statistically significant relationship exists between STDTA and TDTA measures of capital structure and the Tobin's Q. The relationship between LTDTA and Tobin's Q is positive whereas the control variable (firm size) shows a significantly negative relationship with the performance variable measured by Tobin's Q, as large size firms shows inefficiency and affects the firm performance negatively.

\section{Conclusion}

This research was attempted to explore the relationship of capital structure decisions with the firms performance of 36 engineering sector firms in Pakistan listed on the KSE for the period 2003-2009. The analysis is performed by using panel econometric technique called Pooled Ordinary Least Square regression.

The descriptive statistics results showed that the performance of the firms in the engineering sector of Pakistan was not satisfactory during the study period. Firms in Pakistan are leveraged and 52 percent of the firm assets are financed with short term debt and only 9 percent with the long term debt. It may be due to the small and undeveloped debt market and the equity markets are also limited combined with lower levels of trading. Therefore, firms 


\section{Mll Macrothink}

International Journal of Accounting and Financial Reporting ISSN 2162-3082 2012, Vol. 2, No. 1

mainly rely on the bank debt to finance its operations and capital investment needs. In addition, due to information asymmetry problems and market inefficiency, the cost of external source of financing is much higher and difficult to obtain in the Pakistani market.

Overall the study finds that the firms in the engineering sector of Pakistan have adopted capital structure on the pecking order hypothesis. Due to underdeveloped debt market and inefficient equity market, engineering sector firms are largely financed by short term debt. Banks are the major source of finance in this country and due to information asymmetry problems, weak regulatory structure and volatility in earnings; loans are protected with strict covenants which can force the firms to borrow less. Long term debt is expensive, employed by a few firms with large asset structure but shows a negative relationship with Tobin's Q measure which shows that large size companies are inefficient in utilizing its assets towards improvement in performance. Loopholes in the implementation of accounting standards can be the basis for evading taxes and flow of dividends in an illegal way can be the reason for lower equity positions and increased leverage levels.

Further research should be conducted in the Pakistan's market on the other sectors of the economy to check the consistency of results across the various industries. Addition of new variables or other market based measures to test the relationship of capital structure and firm performances can disclose some new insights from the Pakistani markets. In addition, the inclusion of industry specific and some macroeconomic factors in testing the relationship can also be significant, as highlighted in some of the developing countries.

\section{References}

Abor, J. (2005), "The effect of capital structure on profitability: an empirical analysis of listed firms in Ghana”, Journal of Risk Finance, Vol. 6, pp. 438-47.

Abor, J. (2007), "Debt policy and performance of SMEs: evidence from Ghanaian and South Africa firms", Journal of Risk Finance, Vol. 8, pp. 364-79.

Amidu, M. (2007), "Determinants of capital structure of banks in Ghana: an empirical approach”, Baltic Journal of Management, Vol. 2 No. 1, pp. 67-79.

Berger, A.N. and Bonaccorsi di Patti, E. (2006), "Capital structure and firm performance: a new approach to testing pecking order theory and an application to banking industry", Journal of Banking \& Finance, Vol. 30 No. 4, pp. 1065-102.

Bokpin, G.A. (2009), "Macroeconomic development and capital structure decisions of firms: Evidence from emerging market economies", Studies in Economics and Finance, Vol. 26 No. 2, pp. 129-142.

Bokpin, G.A., Aboagye, A. Q. Q. and Osei, K. A. (2010), "Risk exposure and corporate financial policy on the Ghana Stock Exchange", The Journal of Risk Finance, Vol. 11 No. 3, pp. 323-332.

Brav, A., Graham, J., Harvey, C. and Michaely, R. (2005), "Payout policy in the 21 st century", Journal of Financial Economics, Vol. 77, pp. 483-527.

Chen, J.J. (2004), "Determinants of capital structure of Chinese-listed companies", Journal of Business Research, Vol. 57, pp. 1341-51. 
Chen, J., Chen, M., Liao, W. and Chen, T. (2009), "Influence of capital structure and operational risk on profitability of life insurance industry in Taiwan", Journal of Modelling in Management, Vol. 4 No. 1, pp. 7-18.

Deesomsak, R ., Paudyal, K ., \& Pescetto, G . (2004), “The determinantso f capital structure: evidence from the Asia Pacific region", Journal of Multinational Financial Management, Vol. 14 No. 4/5, pp. 3 87-405.

Ebaid, I. E. (2009), “The impact of capital-structure choice on firm performance: empirical evidence from Egypt", The Journal of Risk Finance, Vol. 10 No. 5, pp. 477-487.

Frank, M. and Goyal, V. (2003), "Testing the pecking order theory of capital structure", Journal of Financial Economics, Vol. 67, pp. 217-48.

Gleason, K. C., Mathur, L. K., \& Mathur, I. (2000), "The Interrelationship between Culture, Capital Structure, and Performance: Evidence from European Retailers", Journal of Business Research, Vol. 50 No. 2, pp. 185- 191.

Graham, J. and Harvey, C. (2001), "The theory and practice of corporate finance: evidence from the field", Journal of Financial Economics, Vol. 60, pp. 187-243.

Hadlock, C. and James, C. (2002), "Do banks provide financial slack?", Journal of Finance, Vol. 57, pp. 1383- 420.

Harris, M. and Raviv, A. (1990), "Capital structure and the informational role of debt", Journal of Finance, Vol. 45, pp. 321-49.

Huang, G. \& Song, F. M. 2006, "The determinants of capital structure: Evidence from China", China Economic Review, Vol. 17 No. 1, pp. 14-36.

Jensen, M.C. and Meckling, W.H. (1976), "Theory of the firm: managerial behavior, agency costsand ownership structure", Journal of Financial Economics, Vol. 3, pp. 305-60.

Jensen, M.C. (1986), "Agency costs of free cash flow, corporate finance, and takeovers", American Economic Review, Vol. 76, pp. 323-9.

Karadeniz, E., Kandir, S.Y., Balcilar, M. and Onal, Y. B. (2009), "Determinants of capital structure: evidence from Turkish lodging companies", International Journal of Contemporary Hospitality Management, Vol. 21 No. 5, pp. 594-609.

Kinsman, M. and Newman, J. (1999), "Debt level and firm performance: an empirical evaluation”, paper presented at 28th Annual Meeting of the Western Decision Science Institute, 1999, Puerto Vallarta, Mexico.

Miller, M. H. (1977), “Debt and taxes”, Journal of Finance, Vol. 32 No. 2, p. 261.

Modigliani, F. and Miller, M. (1958), "The cost of capital, corporate finance and thetheory of investment”, American Economic Review, Vol. 48, pp. 261-97.

Modigliani, F. \& Miller, M. H. (1963), "Corporate Income Taxes and the Cost of Capital: A Correction”, $\quad$ American Economic Review, Vol. 53 No. 3, p. 433.

Myers, S.C. (1984), "The capital structure puzzle", Journal of Finance, Vol. 39, July, pp. 575-92.

Myers, S.C. and Majluf, N.S. (1984), "Corporate financing and investment decisions when firms have information that investors do not have", Journal of Financial Economics, Vol. 


\section{MInstitute ${ }_{\text {Mnk }}^{\text {Macrothin }}$}

International Journal of Accounting and Financial Reporting

13, pp. 187-221.

Omran, M. M. and Pointon, J. (2009), "Capital structure and firm characteristics: an empirical analysis from Egypt", Review of Accounting and Finance, Vol. 8 No. 4, pp. 454-474.

Onaolapo, A. A. and Kajola, S. O. (2010), "Capital Structure and Firm Performance: Evidence from Nigeria", European Journal of Economics, Finance and Administrative Sciences, Issue, 25, pp.70-82.

San, O.T. and Heng, T.B. (2011), "Capital Structure and Corporate Performance of Malaysian Construction Sector", International Journal of Humanities and Social Science, Voi.1 No.2. pp.28-36.

Seppa, R. (2008), "Capital structure decisions: research in Estonian non-financial companies", Baltic Journal of Management, Vol. 3 No. 1, pp. 55-70.

Sheikh, N. A. and Wang, Z. (2011), "Determinants of capital structure: An empirical study of firms in manufacturing industry of Pakistan", Managerial Finance, Vol. 37 No. 2, pp. 117-133.

Simerly, R. and Li, M. (2000), "Environmental dynamism, financial leverage and performance: a theoretical integration and an empirical test", Strategic Management Journal, Vol. 21, pp. 31-49.

Shah, A. and Khan, S. (2007), "Determinants of Capital Structure: Evidence from Pakistani Panel Data", International Review of Business Research Papers, Vol. 3 No. 4, pp. 265-282.

Shergill, J. \& Sarkaria, M. (1999),'Impact of Industry Type and Firm Characteristicso n Firm- Financial Performance-- Evidence from Indian Industry level", Journal of Entrepreneurship, Vol. 8 No. 1.

Upneja, A. and Dalbor, M. C. (2001), "An Examination of Capital Structure in the Restaurant Industry", International Journal of Contemporary Hospitality Management, Vol. 13 No.2, pp. 54-59.

Welch, I. (2004), “Capital structure and stock returns", Journal of Political Economy, Vol. 112, pp. 106-31.

Zeitun, R. and Tian, G. (2007), "Capital structure and corporate performance: evidence from Jordan”, $\quad$ Australasian Accounting Business and Finance Journal, Vol. 1, pp. 40-53. 